\title{
FENOMENA PENGANTIN MUDA: \\ Menelusuri Praktik Pernikahan dan Poligami Pada Pasangan di Bawah Umur
}

\author{
Fadillatul Nisa $^{1}$, Rini Marlena ${ }^{2}$ \\ fadillatulnisa.fn@gmail.com, rinimarlena012@gmail.com
}

\begin{abstract}
Abstrak: Masalah pokok dalam penelitian ini adalah bagaimana praktik pernikahan dan poligami pada pasangan di bawah umur yang terdapat di Desa Pandan, Kec. Rimbo Ulu, Kab. Tebo, Provinsi Jambi. Penelitian ini merupakan penelitian lapangan (field research) yang bertujuan untuk mendeskripsikan bagaimana praktik pernikahan dan poligami pada pasangan di bawah umur pada Desa Pandan. Hasil penelitian menunjukkan hal-hal sebagai berikut: 1) pernikahan dan poligami pada pasangan di bawah umur umumnya terjadi karena pergaulan bebas hingga hamil di luar nikah; 2) pernikahan dilakukan tanpa adanya dispensasi nikah dan izin untuk berpoligami dari pengadilan; 3) pihak-pihak yang menyelenggarakan pernikahan ini adalah keluarga dan ninik mamak; serta 4) pernikahan dan poligami pada pasangan di bawah umur rentan terhadap konflik rumah tangga yang akhirnya berujung pada perceraian.
\end{abstract}

Kata Kunci: poligami, pernikahan dini

\section{PENDAHULUAN}

Catatan Badan Pusat Statistik (BPS) pada tahun 2010 mengungkap bahwa sebanyak 25.147 anak di Provinsi Jambi telah melakukan pernikahan di bawah usia 19 tahun. Praktik pernikahan ini menyalahi aturan yang dimuat dalam Undang-Undang Pernikahan No. 1 Tahun 1974 pada pasal 7 ayat (1) bahwa "pernikahan hanya diizinkan jika pihak pria sudah mencapai umur 19 (sembilan belas) tahun dan pihak wanita sudah mencapai umur 16 (enam belas) tahun". Usia yang disebutkan dalam UU ini yang kemudian diperkuat oleh Kompilasi Hukum Islam (KHI) pasal 15 merupakan batasan minimal. Artinya, pernikahan hanya boleh dilakukan jika calon mempelai pria sekurang-kurang telah berusia 19

\footnotetext{
1 Penulis merupakan aktivis di Pusat Studi Gender dan Anak, Lembaga Penelitian dan Pengabdian Masyarakat IAIN Batusangkar

2 Penulis merupakan mahasiswa Jurusan Ahwal Al Syakhsiyah Fakultas Syariah IAIN Batusangkar
} 
tahun dan calon mempelai wanita sekurang-kurangnya telah berusia 16 tahun. Jika pernikahan dilakukan di bawah batasan usia yang telah ditetapkan ini maka disebut sebagai pernikahan di bawah umur.

Angka yang dirilis oleh BPS di atas begitu fantastis. Namun dalam tataran praktis, kenyataan tentang pernikahan anak di bawah umur di Provinsi Jambi jauh lebih mengejutkan karena ada beberapa kasus yang tidak hanya melibatkan penyatuan 1 orang suami dengan 1 orang istri saja melainkan 1 orang suami dengan 2 orang istri (poligami). Praktik poligami pada pasangan di bawah umur ini salah satunya dapat ditemui di Desa Sungai Pandan Kecamatan Rimbo Ulu Kabupaten Tebo. Sejak tahun 2012 sampai tahun 2016 telah terjadi 3 kasus poligami pada pasangan di bawah umur (Purnam, 17 April 2017). Pihak suami dalam keluarga yang berpoligami yang kesemuanya berusia di bawah batasan minimal UU, yaitu DA (17 tahun), MD (18 tahun) dan HR (15 tahun). Sedangkan istri-istri ketiga pelaku poligami ini memiliki kisaran usia antara 13 - 19 tahun.

Praktik poligami pada pasangan di bawah umur ini tidak sesuai dengan ketentuan tentang asas pernikahan di Indonesia yang menganut asas monogami. Pandangan bahwa pada dasarnya setiap orang, baik laki-laki maupun perempuan, hanya boleh memiliki 1 pasangan saja. Batasan ini termaktub dalam UndangUndang Pernikahan pasal 3 ayat (1) yang menyatakan bahwa "pada azaznya dalam suatu pernikahan seorang pria hanya boleh mempunyai seorang istri. Seorang wanita hanya boleh mempunyai seorang suami”. Meski tidak menutup kemungkinan, jika istri tidak mampu menjalankan tugasnya maka asas poligami bisa diberlakukan. Hal ini sesuai dengan pasal 3 ayat (2) menjelaskan, "pengadilan, dapat memberi izin kepada seorang suami untuk beristri lebih dari seorang apabila dihendaki oleh pihak-pihak yang bersangkutan".

Fenomena tentang praktik poligami pada pasangan di bawah umur di Desa Pandan menarik untuk dikaji lebih jauh. Pertanyaannya, Bagaimana praktik pernikahan poligami pada pasangan di bawah umur itu dilakukan? Apakah pernikahan itu melewati prosedur dispensasi nikah atau tidak? Apakah pernikahan kedua (poligami) mendapat izin dari Pengadilan Agama atau tidak? Apakah Siapa saja pihak-pihak yang terlibat dalam aktivitas itu? Apa faktor-faktor yang 
mempengaruhi terjadinya praktik poligami pada pasangan di bawah umur? Lalu alasan apa yang melatarbelakangi terjadinya pernikahan itu? Kesemua pertanyaan-pertanyaan itu akan diurai jawabannya dalam tulisan ini.

\section{METODE PENELITIAN}

Penelitian ini adalah penelitian lapangan (field research) yaitu melihat kenyataan yang ada dilapangan mengenai Praktik Poligami di Desa Sungai Pandan Kecamatan Rimbo Ulu Kabupaten Tebo Provinsi Jambi. Sumber data primer adalah 1) DA, NH, HR, IL dan NA sebagai pasangan yang melakukan poligami di bawah umur; 2) Muhammad Sabar dan Jailani selaku ninik mamak; 3) Muhtadi dan Sulaiman selaku tokoh Agama; dan 4) Musa sebagai pihak KUA (Kantor Urusan Agama) di Desa Sungai Pandan Kecamatan Rimbo Ulu Kabupaten Tebo Provinsi Jambi. Sumber data data sekunder dalam penelitian ini adalah buku-buku yang berkaitan dengan penelitian, UU NO. 1 tahun 1974 dan Kompilasi Hukum Islam (KHI).

Data yang dikumpulkan melalui wawancara dan dokumentasi dianalisis melalu tiga tahapan dengan berpedoman pada pendapat Lexy J. Moleong (2006: 249). Tahapan yang dimaksud adalah: 1) Mencatat yang menghasilkan catatan lapangan, dengan hal itu diberi kode agar sumber datanya tetap dapat ditelusuri; 2) mengumpulkan, memilah-milah, mengklasifikasikan, mensintesiskan, membuat ikhtisar dan membuat indeksnya; dan 3) berpikir, dengan jalan membuat agar kategori data itu mempunyai makna, mencari dan menemukan pola dan hubungan lalu membuat temuan-temuan umum.

\section{PRAKTIK POLIGAMI PADA PASANGAN DI BAWAH UMUR}

Pernikahan di bawah umur pada dasarnya dilarang meski UU pernikahan mengatur bahwa alasan tertentu bisa menjadi dalil legal bagi pelaksanaannya. Pasangan yang akan menikah dan belum memenuhi batasan usia yang ditetapkan wajib meminta dispensasi nikah agar pernikahannya tercatat dan memiliki kekuatan hukum tetap. Begitu juga dengan praktik poligami. Pasangan yang ingin berpoligami harus meminta izin dari pengadilan. Izin tersebut dapat diberikan jika 
alasan berpoligami sesuai dengan ketentuan yang ditetapkan oleh UU pernikahan dan Kompilasi Hukum Islam (KHI). Kesemua aturan itu bertujuan menjamin kesejahteraan keluarga dan menjaga kemashalatan hidup berkeluarga.

Namun dalam praktiknya, masih ada pihak-pihak yang belum memiliki kesadaran akan hal di atas. Bagi sebagian orang pernikahan dipandang sah apabila telah memenuhi syarat-syarat yang diajukan oleh agama. Sedangkan ketentuanketentuan negara yang mengatur tentang pernikahan sering terabaikan dan kurang dipedulikan. Hal ini yang terjadi di Desa Pandan. Berdasarkan wawancara yang dilakukan terhadap responden penelitian mengenai pernikahan dibawah umur tanpa Dispensasi nikah dan poligami anak di bawah umur tanpa izin pengadilan. Responden yang dimaksud meliputi: 1) pelaku pernikahan di bawah umur tanpa dispensasi nikah dan poligami anak di bawah umur tanpa izin pengadilan; 2) Ninik Mamak; 3) Pemuka Agama dan Ketua Kantor Urusan Agama (KUA). Untuk gambaran lebih lanjut dapat dilihat dalam uraian di bawah ini:

\section{Pelaku pernikahan di bawah umur tanpa Dispensasi nikah dan poligami anak di bawah umur tanpa izin Pengadilan di Desa Sungai Pandan}

Ada tiga pasangan yang melakukan pernikahan di bawah umur kemudian berpoligami di Desa Pandan. Pasangan yang dimaksud adalah: 1) DA (suami) dengan NH (istri 1) dan VK (istri 2); 2) MD (suami) dengan AC (istri 1) dan NHA (istri 2); dan 3) HR (suami) dengan IL (istri 1) dan NA (istri 2). Untuk gambaran lebih jauh dapat dilihat dalam tabel di bawah ini:

Tabel 1. data poligami anak di bawah umur di Desa Sungai Pandan sejak tahun 2012-2016

\begin{tabular}{|c|c|c|c|c|c|c|c|}
\hline \multirow{2}{*}{ No } & \multicolumn{3}{|c|}{ Nama pasangan } & \multicolumn{3}{c|}{ Umur } & \multirow{2}{*}{ Izin } \\
\cline { 2 - 7 } & Suami & Istri 1 & Istri 2 & Suami & Istri 1 & Istri 2 & pengadilan \\
\hline 1 & DA & NH & VK & 17 & 15 & 13 & Tidak \\
\hline 2 & MD & AC & NHA & 18 & 19 & 17 & Tidak \\
\hline 3 & HR & IL & NA & 18 & 15 & 15 & Tidak \\
\hline
\end{tabular}

*Diolah dari hasil wawancara dengan Purnam, Kepala Dusun Komplek Baru Desa Pandan 
Berangkat dari data di atas wawancara terhadap pelaku pernikahan di bawah umur tanpa dispensasi nikah dan poligami tanpa izin pengadilan pun dilakukan. Responden pertama adalah DA (17 tahun), suami dari NH (15 tahun) dan VK (13 tahun). Wawancara yang dilakukan pada hari Rabu tanggal 14 Juni 2017 berhasil mengungkap alasan pernikahan di bawah umur yang dilakukan oleh DA dengan NH. Pernikahan itu terjadi karena dengan DA dan NH tertangkap oleh masyarakat ketika sedang bermesraan sehingga harus dinikahkan. Prosesi ijab kabul dilakukan oleh ninik mamak di Desa Sungai Pandan yaitu Muhammad Sabar sebagai pengganti KUA.

Pernikahan itu dilakukan tidak dicatatkan ke Kantor Urusan Agama (KUA) sehingga bisa dipastikan tidak memiliki dispensasi nikah. Padahal Ninik Mamak telah menjelaskan mengenai aturan-aturan dalam pernikahan, untuk didaftarkan ke KUA kemudian untuk melakukan dispensasi nikah ke Pengadilan, namun pihak keluarga merasa keberatan karena menimbang faktor ekonomi yang masih lemah dan juga menimbang jarak tempuh antara Desa Sungai Pandan dengan Pengadilan Agama yang sangat jauh, oleh karena itu pihak keluarga memilih pernikahan tanpa tercatat secara resmi. Keabsahan pernikahan itu hanya dilihat dari keterpenuhan rukun pernikahan menurut hukum Islam, yaitu adanya kedua calon mempelai, wali yaitu Bapak Mamad (Bapak Kandung NH), dua orang saksi yaitu (Bapak Umar dan Bapak Yahya) dan Ijab Qabul.

Selanjutnya, DA diminta konfirmasinya mengenai praktik poligami yang dilakukan. DA beranggapan bahwa poligami yang ia lakukan sama halnya dengan pernikahan di bawah umur. Praktik poligami ini terjadi karena VK telah hamil di luar nikah sehingga harus dinikahi. Konsekwensi dari perbuatannya adalah DA harus mempunyai 2 (dua) orang istri di usia yang masih belia. Prosesi pernikahan kedua DA dilakukan oleh ninik mamak yaitu Bapak Sholeh di Desa Tanah Periuk (Kabupaten Bungo), karena ninik mamak di Desa Sungai Pandan melarang keras poligami yang DA lakukan. Alasan penolakan oleh ninik mamak di Desa Sungai Pandan, dikarenakan poligami ini dilakukan oleh anak-anak yang masih di bawah umur. 
Sama halnya dengan pernikahan pertama DA yang dilakukan tanpa dispensasi nikah, pernikahan kedua (poligami) juga dilaksanakan tanpa izin dari pengadilan. Izin dari istri pertama DA pun hanya izin lisan saja. Keabsahan pernikahan ini kembali hanya dilihat dari keterpenuhan rukun dari pernikahan menurut hukum Islam. Pada pernikahan kedua DA ini, Bapak Jarkoni (ayah kandung VK) menjadi wali nikah. Sedangkan saksi pernikahannya adalah Bapak Ibrahim dan Bapak Irwan. DA tidak menyadai dan tidak memahami bahwa konsekwensi dari pernikahan yang tidak didaftarkan secara resmi kepada negara adalah administrasi kependudukan menjadi kacau balau. Anak-anak yang akan lahir dari pernikahan itu tidak memiliki dokumen-dokumen seperti akte kelahiran dan lain sebagainya.

Pernikahan di usia belia, terlebih dengan 2 istri membuat DA keteteran. Pasalnya, usia yang masih muda membuat kepribadian DA belum matang secara sempurna. Sepanjang perjalanan pernikahan, DA mengalami banyak kesulitan dalam menghadapi kedua istrinya. Meskipun DA sudah berusaha untuk bersikap adil namun kedua istrinya selalu saja bertengkar, bahkan untuk hal-hal remeh sekali pun. Kondisi itu kian dipersulit oleh kenyataan bahwa kedua istri DA dan anak-anaknya tinggal dalam satu rumah. Itu pun rumah orang tua DA. Usia belia dan tingkat pendidikan yang tidak memadai membuat DA belum bisa mapan untuk hidup mandiri dan menyediakan rumah untuk istri-istrinya. Ketidakmandirian ekonomi juga menjadi alasan kenapa DA memilih menempatkan kedua istrinya didalam satu rumah bersama orang tuanya.

Pertanyaan serupa juga diutarakan kepada istri-istri DA. Namun hanya NH yang berhasil diwawancarai, sementara VK sedang berada dalam kondisi sakit sehingga tidak memungkinkan untuk diwawancarai. NH kembali mengatakan bahwa pernikahan ia lakukan dengan DA terjadi karena tertangkap oleh masyarakat yang kemudian harus menikah. Ketika ditanyakan tentang poligami suaminya, NH menceritakan bahwa sebelum melakukan pernikahan pihak keluarga dengan ninik mamak di Desa Sungai Pandan telah melakukan pertemuan untuk persiapan pernikahan kedua DA tetapi dengan hasil ninik mamak enggan 
menikahkan DA dengan alasan DA masih mempunyai istri dan sama-sama masih di bawah umur.

NH penolakan yang diberikan oleh ninik mamak di Desa Pandan, pihak keluarga DA dan keluarga VK memutuskan pernikahan akan digelar di Desa Tanah Periuk, Kabupaten Bungo. Sebelum Ijab Qabul diikrarkan, ninik mamak menanyakan kesediaan $\mathrm{NH}$ untuk mengizinkan DA menikah dengan VK. NH memberkan izin suaminya untuk berpoligami meski bathinnya sangat berat merelakan pernikahan itu. Izin ini tidak dituliskan melaikan hanya secara lisan. Keputusan NH memberi izin berpoligami pada suaminya memberi dampak yang serius terhadap kehidupan rumah tangganya dengan DA. Banyak kesulitan yang dirasakan. Mulai dari masalah keuangan hingga kurangnya waktu untuk bersama dengan DA, apalagi NH dan VK tinggal bersama di rumah orang tua DA.

Responden kedua dalam penelitian ini adalah HR (18 tahun) dengan istriistrinya IL (15 tahun) dan NA (15 tahun). Wawancara dilakukan pada hari Kamis tanggal 15 Juni 2017. Pernikahan pertama, HR dinikahkan oleh ninik mamak yaitu Bapak Muhammad Sabar sebagai pengganti pihak KUA. Pernikahan yang dilakukan tidak tercatat secara resmi hanya dengan memenuhi rukun pernikahan menurut hukum Islam. Wali dalam pernikahan HR dan IL adalah ayah kandung IL yaitu Bapak Safarudin dan yang menjadi saksi dalam pernikahannya adalah Bapak Jailani dan Bapak Suprianto. HR mengutarakan bahwa orang tuanya enggan untuk mendaftarkan pernikahannya di KUA Rimbo Ulu karena alasan mereka malu karena pernikahan ini. Kehamilan di luar nikah akibat pergaulan bebas mengakibatkan orang tua HR menikahkan anaknya hanya secara hukum Islam.

HR kemudian ditanyai tentang praktik poligaminya. Menurut HR, poligami baginya adalah pernikahan dengan dua orang istri dalam waktu yang bersamaan. Dalam pelaksanaan poligami yang HR lakukan dengan NA, proses ijab qabul dinikahi oleh ninik mamak yaitu Bapak Muhammad Sabar dengan memenuhi rukun pernikahan menurut hukum Islam. Wali dalam pernikahan HR dan NA adalah ayah kandung dari NA yaitu Nazarudin Ishak. Sedangkan saksi dalam pernikahan keduanya ini adalah Purnam dan (ALM) Idris. Hal menarik 
dalam pernikahan kedua ini adalah beda waktu pernikahan pertama dan kedua HR hanya berbeda beberapa hari saja. Hal ini dikarenakan kedua istrinya sama-sama hamil di luar nikah sehingga harus dinikahi keduanya dalam waktu dekat. Kehamilan di luar nikah dan jarak pernikahan pertama dan kedua yang begitu dekat membuat keluarga enggan mendaftarkan pernikahannya ke KUA dan meminta izin pengadilan untuk melakukan poligami.

HR mengungkapkan banyak hal yang dialaminya dalam pernikahan poligaminya. Dilema memiliki dua istri dalam waktu bersamaan dengan konsekwensi menanggung keseluruhan biaya hidup kedua istrinya membuat kewalahan. Hingga dalam kurun waktu satu setengah tahun ia menyerah dengan menceraikan istri pertamanya, IL. HR berdalih bahwa pernikahannya dengan IL membuatnya tidak nyaman sehinngga perceraian menjadi pilihan. Selama memiliki dua istri, HR merasa kesulitan dalam membagi waktu dan keuangan. Untuk mengenai tentang peratuan yang mengatur tentang pernikahan seperti Undang-Undang Pernikahan, Undang-Undang Perlindungan Anak dan Kompilasi Hukum Islam HR mengaku tidak mengetahui tentang bagaimana proses pernikahan dan proses berpoligami yang telah di tetapkan dalam Undang-Undang.

IL, mantan istri HR yang diwawancarai pada hari Selasa, 20 Juni 2017 mengatakan bahwa pelaksanaan pernikahannya dengan HR dilaksanakan di Desa Sungai Pandan dan di Nikahkan oleh ninik mamak di Desa Sungai Pandan yaitu Bapak Muhammad Sabar, ninik mamak ini sebagai pengganti dari orang KUA. Wali dalam pernikahan ini adalah Bapak Safarudin dan yang menjadi saksi dalam pernikahannya adalah Bapak Jailani dan Bapak Suprianto, namun pernikahan ini tidak tercatat secara resmi dan tidak adanya buku nikah. Pengalaman IL selama poligami membuat trauma yang mendalam. IL mengatakan bahwa seandainya ia mengetahui sejak awal akibat dari pergaulannya yang terlalu bebas, pasti ia akan lebih berhati-hati dalam bergaul. Sayangnya nasi telah menjadi bubur, kini ia diceraikan oleh HR setelah sebelumnya di poligami.

Wawancara dilanjutkan dengan NA (15 tahun). Istri kedua HR yang diwawancarai pada hari Sabtu tanggal 16 Juni 2017 itu mengatakan bahwa 
pelaksanaan pernikahannya dengan HR terjadi disebabkan karena telah terjadi hamil diluar nikah. Pernikahan yang mereka laksanakan tanpa adanya pegawai pencatat nikah dan hanya dilaksanakan oleh ninik mamak yaitu Bapak Muhammad Sabar. Wali nikah adalah Bapak Nazarudin Ishak ayah kandung dari IL dan yang menjadi saksi adalah Purnam dan Bapak (ALM) Idris. Menurut NA, pernikahannya dengan HR berjalan dengan baik setelah berpisahan HR dengan IL. Berbagai masalah terjadi sebelum perceraian HR dengan IL, namun saya masih bisa bersyukur hingga saat ini pernikahannya dengan HR masih baik-baik saja.

Responden ketiga dalam penelitian ini MD (18 tahun) dengan istri-istrinya AC (19 tahun) dan NHA (17 tahun). Namun data dari pasangan poligami di bawah umur ini tidak bisa diperoleh karena sudah pindah dari Desan pandan ke daerah lain. Upaya pelacakan melalui pihak keluarga pasangan poligami ini tidak membuahkan hasil. Tempat tinggal MD, AC dan NHA saat ini tidak diketahui. Ketika dikonfirmasi kepada keluarganya, jawaban yang diberikan terkesan mengambang. Keluarga sepertinya kurang terbuka dalam memberikan informasi tentang pasangan poligami yang ketiga ini.

\section{Ninik Mamak di Desa Sungai Pandan yang ikut serta melaksanakan pernikahan di bawah umur}

Muhammad Sabar selaku ninik mamak di Desa Sungai Pandan diwawancarai pada hari Sabtu tanggal 10 Juni 2017. Ia mengungkapkan bahwa pernikahan dibawah umur yang terjadi di Desa Sungai Pandan telah memenuhi rukun pernikahan dalam Islam. Ia melanjutkan bahwa pernikahan tersebut sudah menyalahi aturan negara sehingga pernikahan ini menjadi pernikahan sirri, pernikahan yang tidak tercatat. Pernikahan di bawah umur dilaksanakan sebagaimana adat istiadat yang berlaku di Desa Sungai Pandan, yaitu dinikahkan oleh ninik mamak setempat sebagai pengganti dari pihak KUA, tetapi pelaksanaan pernikahan tetap berpegang pada hukum Islam dengan memenuhi rukun pernikahan, dengan wali yang ayah kandung dari calon pengantin wanita dan saksinya adalah mamak dari kedua belah pihak.

Sabar menambahkan jika terjadi pekawinan di bawah umur banyaknya masyarakat yang enggan untuk mendaftarkan pernikahan tersebut ke KUA dengan 
alasan enggan untuk melakukan dispensasi nikah, kerena untuk melakukan dispensasi nikah banyak hal yang harus dilalui. Hal ini ditambah lagi dengan jarak tempuh antara Sungai Pandan dengan Pengadilan Agama sangat jauh sehingga akan banyaknya memakan biaya dan waktu. Padahal sebelum pernikahan, para ninik mamak, tokoh agama dan kerabat terdekat dari kedua calon pengantin harus merundingkan/ bermusyawarah terlebih dahulu tentang perencanaan pernikahan dirumah calon pengantin. Dalam pertemuan ini calon pengantin akan diberi nasehat atau gambaran dalam membina rumah tangga, sekaligus menjelaskan tentang bagaimana pernikahan yang diatur dalam Undang-Undang Pernikahan, pada saat pertemuan tersebut siapa saja boleh memberikan nasehat untuk calon pengantin.

Sabar kemudian menceritakan tentang poligami di bawah umur yang terjadi Desa Sungai Pandan pada tahun 2012. Ia menikahkan pasangan poligami tersebut, saat HR menikah dengan IL dan NA. Pernikahan dilaksanakan karena memang disebabkan karena IL dan NA tengah hamil oleh HR, keluaga IL dan NA meminta pertanggung jawaban dari HR untuk menikahi anak mereka. Sabar menyadari bahwa pernikahan ini sangat salah. Pasalnya, pertama pernikahan di bawah umur tanpa dispensasi nikah, kemudian ditamnah lagi dengan berpoligami tanpa izin pengadilan. Didalam Islam pun sedah di jelaskan bagaimana syaratsyarat dari berpoligami, namun pihak keluarga memaksa untuk melaksanakan pernikahan dengan mempertimbangan IL dan NA tengah hamil, kemudian jika pernikahan mereka di daftarkan ke KUA, pihak KUA meminta mereka untuk meminta surat izin dari pengadilan (Dispensasi nikah), untuk mengurus hal tersebut akan mengabiskan banyak biaya dan waktu karena jarak tempuh pengadilan yang sangat jauh dari Desa Sungai Pandan. Sama halnya dengan penjelasan mengenai pernikahan dibawah umur, pernikahan yang dilakukan HR dengan IL dan HR dengan NA telah sesuai dengan rukun pernikahan secara agama telah sah menjadi suami istri.

Sabar menambahkan bahwa dalam beberapa tahun terakhir terdapat 3 kasus poligami anak dibawah umur. Hal ini terjadinya karena adanya paksaan dari 
keluarga dan karena suatu hal yang menyebabkan mereka wajib untuk menikah. Usaha ninik mamak untuk mencegah terjadinya poligami dibawah umur untuk kedepannya telah kami lakukan, dengan melarang keras jika terjadi hal tersebut. Namun hal tesebut tidak bisa dijadikan panduan karena setelah kasus yang terjadi pada tahun 2012, pada tahun 2014 dan 2015 hal tersebut terulang kembali. Menurut beliau, poligami anak di bawah umur memang sudah menyalahi aturan yang berlaku seperti Undang-Undang Pernikahan dikarenakan berbagai alasan dari kedua belah pihak keluarga.

Responden kedua dari kalangan ninik mamak pada penelitian ini adalah Jailani. Ninik mamak di Desa Sungai Pandan yang diwawancarai pada hari Minggu tanggal 11 Juni 2017 ini menjelaskan bahwa pernikahan dibawah umur yang terjadi di Desa Sungai Pandan telah sesuai ketentuan Agama dengan memenuhi rukun pekawinan. Jailani menambahkan bahwa pernikahan ini memang telah menyalahi aturan Undang-Undang Pernikahan, karena di dalam Undang-Undang pernikahan telah dijelaskan mengenai batas usia pernikahan dan prosedur pernikahan. Namun, sebagian masyarakat enggang untuk mendaftarkan ke KUA jika pernikahan tersebut dilakukan oleh anak dibawah umur dengan alasan keberatan untuk melakukan dispensasi nikah ke Pengadilan Agama, sebab jarak tempuh yang jauh. Oleh sebab itu mereka memilih untuk memikah dengan ninik mamak setempat.

Jailani melanjutkan bahwa masalah pernikahan yang terjadi di pada zaman sekarang memang sangat memperihatinkan, pernikahan di bawah umur sudah umum kita dengar, namun poligami dibawah umur sangat jarang kita temukan, tapi itu nyata yang terjadi di Desa Sungai Pandan, batas umur untuk melaksakan pernikahan telah keluar dari jalur Undang-Undang kemudian ditambah lagi dengan poligami yang juga tidak ada izinya secara resmi. Namun pernikahan yang dilaksanakan telah sesuai dengan ketuentuan adat istiadat dan agama. Hanya saja perkaiwnannya tidak resmi secara hukum, sebagai ninik mamak kami tidak sembarangan untuk menikahkan penakan kami, kami harus melihat penyebab 
terjadinya pernikahan tersebut. Poligami dibawah umur ini terjadinya karena desakan dari pihak perempuan.

Tokoh Agama dan pihak Kantor Urusan Agama (KUA) mengenai pandangan pernikahan di bawah umur dan poligami anak di bawah umur yang terjadi di Desa Sungai Pandan

Wawancara dengan Muhtadi, tokoh agama di desa Sungai Pandan dilakukan pada hari Minggu tanggal 11 Juni 2017. Ia mengungkapkan bahwa pelaksanaan pernikahan dan poligami pada pasangan dibawah umur dilakukan oleh ninik mamak. Artinya pernikahan itu digelar secara adat dan agama saja. Ketidakhadiran pegawai pencatat nikah menandakan bahwa pernikahan itu dilakukan tanpa dispensasi nikah maupun izin poligami dari pengadilan. Muhtadi melanjutkan, terkait posisinya sebagai tokoh agama sekaligus sekretaris desa Pandan, telah banyak upaya yang dilakukan agar masyarakat taat terhadap hukum termasuk hukum perkawinan. Namun karena situasi dan kondisi yang kurang memungkinkan, keberadaan UU perkawinan kadang terabaikan oleh masyarakat.

Kebanyakan pasangan yang melakukan pernikahan dibawah umur dikarenakan berbagai alasan. Mulai dari masalah keuangan, malu karena pergaulan bebas sampai pada alasan banyaknya waktu yang dihabiskan jika harus meminta izin dari pengadilan. Muhtadi melanjutkan bahwa telah terjadi beberapa kasus pernikahan dibawah umur tanpa adanya dispensasi nikah dan izin untuk berpoligami dari pengadilan. Pernikahan dengan istri pertama tidak disertai dengan pencatatan nikah secara resmi. Kemudian pernikahan dengan istri kedua juga mengalami hal yang serupa tanpa izin dari pengadilan sehingga dilakukan secara sirri'. Pernikahan pertama yang tidak terdaftar di KUA menjadi penyebab pernikahan kedua (poligami) juga tidak bisa didaftarkan. Sehingga, ibarat mata rantai, keduanya saling pengaruh mempengaruhi membuat kedua pernikahan menjadi tidak terdaftar.

Praktik pernikahan dan poligami pada pasangan di bawah umur yang tidak mendapat dispensasi dan izin pengadilan, dilakukan oleh ninik mamak. Prasyarat poligami hanya persetujuan istri pertama. Persetujuan itu disampaikan secara lisan di hadapan ninik mamak, tokoh agama dan para kerabat. Tidak ada persetujuan 
secara tertulis dari pihak istri pertama. Muhtadi mengemukakan pandangannya bahwa memang Islam memperbolehkan poligami dengan syarat suami mampu berlaku adil terhadap istri-istri dan anak-anakya. Keadilan itu dilihat dari berbagai aspek, baik lahir mau pun bathin. Jika meninjau praktik poligami yang dilakukan oleh suami di bawah umur, keadilan itu akan sulit diterapkan. Hal ini dikarenakan kejiwaan suami yang belum matang sehingga berimplikasi terhadap kehidupan berumah tangganya.

Responden kedua terhadap toko agama desa Pandan, Sulaiman dilakukan pada hari Minggu tanggal 11 Juni 2017. Pernikahan dibawah umur yang terjadi di Desa Sungai Pandan dalam pandangan Sulaiman terjadi karena pasangannya hamil di luar nikah. Menurut Sulaiman, dalam pelaksanaan pernikahan ninik mamaklah yang mengurus segalanya, mulai dari pertemuan sebelum pernikahan sampai dengan akad nikah. Para pemuka agama tidak ikut serta dalam hal tersebut. Tidak ikutnya para pemuka agama dalam pelaksanaan pernikahan di bawah umur ini bukan berati tokoh agama berlepas tangan. Namun kesemuanya sudah diurus oleh ninik mamak sebagai bentuk tanggung jawab terhadap kaumnya.

Sulaiman menuturkan, pemuka agama, ninik mamak dan beberapa orang dari perangkat desa telah banyak memberikan penjelasan mengenai pernikahan yang di atur dalam Undang-Undang. Namun masih banyak masyarakat yang tidak paham mengenai Undang-Undang Pernikahan. Sudah berulang kali di adakan penyuluhan hukum tentang pekawinan oleh pihak KUA, tetapi sampai saat ini tidak begitu tampak hasilnya. Kemungkin masih awamnya masyarakat kita dengan hukum yang telah berlaku seperti Undang-Undang Pernikahan dan Kompilasi Hukum Islam. Mereka masih berpegang terhadap hukum adat yang telah mereka anut, sehingga mereka tidak mengerti akibat dari pernikahan tanpa adanya buku nikah. Padahal buku nikah itu sangat penting dalam mengurus hal apapun, seperti untuk membuat Akta kelahiran anak, membuat KK dan lain-lain.

Wawancara kemudian dilanjutkan kepada Musa, kepala KUA Rimbo Ulu pada hari Selasa tanggal 13 Juni 2017. Ia menjelaskan bahwa ia tidak mengetahui 
bahwa adanya pernikahan dibawah umur tanpa dispensasi nikah dan poligami anak di bawah umur yang terjadi di wilayahnya. Kalau pun pernikahan dan poligami pada pasangan di bawah umur terjadi di wilayah Rimbo Ulu, maka pernikahan tersebut menyalahi aturan UU perkawinan dan KHI bagi yang beragama Islam. Musa melanjutkan bahwa sepengatahuannya, selama menjabat sebagai Kepala KUA Rimbo Ulu belum pernah ada masyarakat yang mendaftarkan pernikahan di bawah umur atu pun yang meminta dispensasi nikah. Demikian juga dengan masyarakat yang mengurus izin poligami pasangan di bawaah umur.

Musa kemudian ditanyai pendapatnya tentang prakrik pernikahan dan poligami pada pasangan di bawah umur ini, ia mengungkapkan bahwa kejadian ini sangat luar biasa. Hal ini dikarenakan pernikahan dengan istri pertama saja sudah menyalahi aturan UU dan KHI bagi yang beragama Islam. Kemudian ditambah lagi praktik poligami anak yang masih dibawah umur. Islam tidak pernah mengajarkan untuk berpoligami karena dipaksa, untuk melakukan poligami harus memenuhi syarat-syarat yang telah di tetapkan dalam Al-Qur'an. Pada kasus ini, tida ada yang bisa menjamin bahwa anak dibawah umur bisa bersikap adil terhadap istri dan anak-anaknya.

\section{PENUTUP}

Sepanjang paparan hasil penelitian di atas terungkap bahwa memang telah terjadi praktik pernikahan dan poligami pada pasangan di bawah umur di desa Pandan, Kec. Rimbo Ulu, Jambi. Sejak tahun 2012 sampai 2016 telah terjadi 3 pernikahan di bawah umur yang kemudian dilanjutkan dengan pernikahan kedua (poligami). Kasus pernikahan dan poligami pada pasangan di bawah umur umumnya terjadi karena pergaulan bebas hingga hamil di luar nikah. Bahkan ditemui kasus di mana calon pengantin pria menghamili dua orang perempuan sekaligus sehingga pelaksanaan pernikahan pertama dan kedua hanya berjarak beberapa hari.

Selain itu juga ditemukan fakta bahwa pernikahan dilakukan tanpa adanya dispensasi nikah dan izin untuk berpoligami dari pengadilan. Alasan biaya, waktu 
dan jarak yang jauh dari pengadilan agama menjadi alasan. Atas dasar itu, pernikahan hanya diselenggarakan oleh keluarga dan ninik mamak di desa saja. Tidak ada keterlibatan Kantor Urusan Agama dalam pernikahan ini. Bahkan pihak KUA tidak mengetahui bahwa praktik pernikahan dan poligami pada pasangan di bawah umur terjadi di wilayah administratifnya. Terakhir, pernikahan dan poligami pada pasangan di bawah umur rentan terhadap konflik rumah tangga yang akhirnya berujung pada perceraian. 


\section{DAFTAR PUSTAKA}

Azzam Muhammad Aziz Abdul, Hawwas Sayyed Wahhab Abdul, Fiqh Munakahat, Jakarta: Amzah, 2009

Hadikusuma Hilman, Hukum Perkawinan Di Indonesia Menurut UndangUndang, Hukum Agama, Hukum Adat, Bandung: Bandar Maju, 1990

Kustini, Menelusuri Makna Dibalik Fenomena Perkawinan Di Bawah Umur Dan Perkawinan Tidak Tercatat, Jakarta: Puslitbang Kehidupan Keagamaan Badan Litbang Dan Diklat Kementerian Agama RI, 2013

Mardani, Hukum Perkawinan Islam Di Dunia Islam Modern, Yogyakarta: Graha Ilmu, 2011

Muhdlor Zuhdi A, Memahami Hukum Perkawinan, Bandung: Al-Bayan, 1995

Mulia Musdah, Pandangan Islam Tentang Poligami, Jakarta: Lembaga Kajian Agama dan Jender, 1999

Mursalin Supardi, Menolak Poligami Studi Tentang Undang-Undang Perkawinan dan Hukum Islam, Yogyakarta: Pustaka Pelajar, 2007

Ramulyo Idris Mohd, Hukum Perkawinan Islam, Jakarta: Bumi Aksara, 1999

Sabiq Sayyid, Fikih Sunnah 3, Jakarta: Cakrawala Publishing, 2011

Setiady Tahlib, Intisari Hukum Adat Indonesia, Bandung: Alfabet, 2008

Soekanto Soerjono, Sosiologi Keluarga tentang Hal Ikhwal Keluarga, Remaja dan Anak, Jakarta: Rineka Cipta, 2004

Suprapto Bibit, Liku-Liku Poligami, Yogyakarta: Pustaka al-Kautsar,1999

Syarifuddin Amir, Hukum Perkawinan Islam Di Indonesia Antara Fiqh Munakahat Dan Undang-Undang Perkawinan, Jakarta: Prenata Media, 2009

Tihami, Sobari Sahrani, Fikih Munakahat, Jakarta, Rajawali Pres, 2010

Tim Redaksi Fokusmedia, Kompilasi Hukum Islam, Bandung: Fokus Media, 2005

Undang-Undang No.1 Tahun 1974 Tentang Perkawinan

Undang-Undang No. 23 Tahun 2002 Tentang Peradilan Anak 